\title{
Nostalji Perdesi Ve Geçmişi İcat Etmek
}

\author{
Engin Ümer*
}

\section{Özet}

Sinema her zaman rüya sahneleri üretmiştir. Nostalji de bu rüya tarzlarndan biridir. Nostalji, kültürel açıdan modern bir olgu olarak karşımıza çıkmaktadır. Modern olmanın, geçmişi yok sayma veya ondan kopma olması nostaljinin varlık nedeni olmuştur. Geçmişi hatırlama çabası olarak nostalji, kaybedilene karşı derin bir özlem demektir. Sinema da nostalji temsillerini kullanmaktadır. Nostalji temsili eğlence sineması için seyri kolay sahneler üretmek imkanım sunmaktadır. Bu yüzden nostaljinin tarihsel gerçeklikten kopma veya tarihsel gerçekliği yok sayan bir karakteri olduğu söylenebilir. Ancak nostalji, travmatik boyutu olan bir olayın etkilerini de gösterebilir. Etkisi güçlü bir olay, nostalji temsilinde etki gücü farklılaştırılarak izleyicisine sunulabilir. Bu çalışma, Türk sinemasının 2000 sonrası nostalji temsilini nasıl kullandığın ele alma amacındadır. Çalışma modernlik ve nostalji, sinema ve rüya, televizyon ve sinema ikili kavram ve durumlar arasında teorik çerçevesinin kurmaktadır. Bu çerçeve içinden 2000 sonrası ana akım Türk sinemasinda nostalji temsilini ele almaktadır. Amaçlanan ise ele alınan tarih çerçevesinde sinema filmlerinin toplumsal olaylarn gösterme çabasında olduklarıdır. Çalışmada eğlence ve tüketim karakteri taşıyan nostalji temsilinin dönemsel olayların etkilerini hafifletmek ve yeniden değerlendirmek için kullanıldı̆̆ı iddia edilmektedir.

Anahtar Kelime: Nostalji, Sinema, Yeni Türk Sineması, Temsil, Geçmiş, Deneyim

ORCID ID : 0000-0001-9685-3531

E-mail : umerengin@gmail.com

DOI: $10.31122 /$ sinefilozofi.515112

Geliş Tarihi - Recieved: 20.01.2019

Kabul Tarihi - Accepted: 25.04.2019 


\title{
The Veil Of Nostalgia And Inventing The Past
}

\author{
Engin Ümer*
}

\begin{abstract}
Cinema has always featured dream scenes. Nostalgia can also be considered a type of dream. In cultural terms, nostalgia is a modern phenomenon. Nostalgia exists because modernity represents a denial or severing of all ties with the past. In an attempt to remember the past, nostalgia represents a deep yearning for what has been lost. Cinema also makes use of nostalgic representations, as they allow entertainment-oriented cinema to produce easy-to-watch scenes. Accordingly, nostalgia can be said to have a character that diverges from or ignores historical reality. That said, nostalgia also has the ability to demonstrate the effects of traumatic events. Events with a strong message can be presented to viewers by amending their impact via nostalgic representation. This study aims to examine the use of nostalgic representations in Turkish cinema in the post-2000 period. The theoretical framework of the study is based on the dualities of modernity and nostalgia, cinema and dream, and television and cinema. To this end, it focuses on nostalgic representations in post-2000 mainstream Turkish cinema, aiming to show that in taking up history, these films attempt to shed light on social events. The study argues that nostalgic representations, characterized by entertainment and consumption, are used to dilute the effects of historical events and to recycle them.
\end{abstract}

Keywords: Nostalgia, Cinema, New Turkish Cinema, Representation, History, Experience

ORCID ID : 0000-0001-9685-3531

E-mail : umerengin@gmail.com

DOI: 10.31122/sinefilozofi.515112

Recieved - Geliş Tarihi: 20.01.2019

Accepted - Kabul Tarihi: 25.04.2019 


\section{Giriș}

Modernleşme, yeni bir hayatı ve kültürü inşa etse de travmatik olanın da dengelenmeye çalışıldığı bir projedir ${ }^{1}$. Modernleşme, kopuşlar evresi olarak kendinden menkul yenilik kültüne karşılık gelmektedir. Yenilikçilik eskinin, geleneklerin, önceki toplumsal ve kültürel formların dağılmasına işaret etmektedir. Dağılma, büyük bir istek ve sevinç ile karşılanırken meydana gelen krizlerin üstünü örtmek için perdelemelerde bulunmaya ihtiyaç duyulmuştur. Modernliğin anlatısındaki bu boyut, toplumların kimliklerini icat ederken, bir öncekiyle ilişkide olmanın nasıl olabileceğinin bitimsiz şekilde sorgulandığı bir düşünce yığını ve çatışkılı kültürel ilişkiler meydana getirmiştir.

Nostalji, modern olmanın anlatısında söz konusu travmaları perdeleme konusunda çokça kullanılan bir stratejidir. Nostaljinin etimolojik geçmişine karşılık, nostaljinin modern bir olgu olduğu söylenebilir. Nostaljinin gündeminin bitmeyecek gibi olması modernliğin krizlerinin üstünü örtmek zorunda olan tavrıyla ilgili görülebilir. Nostalji, kültürel pek çok formda kendisini gösterebilmiştir. Giyim kuşam modasında, gündelik konuşma dilindeki kimi kelimelerde, çeşitli nesnelerde, televizyon dizilerinde, romanlarda, resimlerde ve elbette sinemada.

Sinema ve nostalji ilişkisi açıkça kökensel ortaklıklarıyla düşünmeye müsaittir². Sinema makinesi belleğin analojisi olarak deneyimin kayıt altına alınmasıdır. Hareket imajlar sadece zaman ve mekan ilgileri içinde olanların belgelenmesi değil, izleyicinin deneyimlerini canlandıran bir tetikleyici anlar dizisi olarak da görülebilir. Bu yüzden sinemanın nostaljik karakteri, belleği tazeleyen ancak rüya sahnelemesiyle de izleyicisine başka bir dünya hayali sunmaktadir.

Nostaljiye dair ilgi onun kaybedilmiş saflığı göstermesiyle alakalı olmuştur. Çünkü temsil açısından nostalji dilinin teamüller üretici yönü, ortaklıkları daha da kolay sağlamakta ve bu kitlesel bir kabul ile karşılanmaktadır. Bu sebepten nostalji, hayal ile gerçeği kaynaştırdığı bir kaybedilmiş olanın sahnelenmesi ve izleyicisine bu kaybın giderilmesini, kısa süreli de sağlamaktadır.

Sinema ve nostaljinin işlevselliği özellikle seyri kolay bir gösterim sunmasıdır. Yine de bunun kendi içinde ters görünebilecek bir özelliği de saklı tuttuğu da iddia edilebilir. Bu nostalji temsilinin travmatik olayı örten, yani kayba neden olan durumu hissettirmeyen, buna karşılık bu olayı hissettirmekten de geri kalmayan ve hatta onunla hesaplaşmak için kullanışlı araç rolü sergileyebilecek olmasıdır. Nostalji temsilinin unutturuculuğu gündelik olandan kaçış ve rüya sahnesinde izleyicinin hayallere dalması iken, bu hayaller içinde kayıplara neden olan olayların temsilinin dolaylı veya kimi yönleriyle, bir hesaplaşma imkanı meydana getireceği de iddia edilebilir³.

\footnotetext{
1 Modernitenin bu tipik anlatısı konusunda sosyal bilimlerde gözle görülü bir literatür söz konusudur. Bunlardan en popüleri Marshal Berman'ın "Katı Olan Her Şey Buharlaşıyor" (2003) kitabıdır. Alain Touraine'in "Modernliğin Eleştirisi" (2000), Charles Taylor'un "Seküler Çă̆" (2014), Peter Wagner'in “Modernliğin Sosyolojisi" (2005) konu hakkında en bilinen çalışmalardır. Sosyolojik ve düşünsel anlamda bu çalışmalar aynı konulu diğerleri gibi moderniteyi güçlü bir üretim ve yıkım evresi olarak ele alırlar.

2 Çalışmamız bu ortaklık üzerinden hareket etmektedir. Sinemada nostalji konusunda yapılan çalışmalar ile onların eleştirisini gerçekleştirmek üzerinden bir fark kurma amacında değildir. Yine de konu hakkında YÖK tez merkezinden ulaşılabilmiş Sezen Gürüf Başekim'in “Türk Sinemasında Nostalji: 2000-2011” (2015) adlı çalışması söz konusu tarih aralığı içinden ele aldığı örnek filmleride neyin nostalji ile ilgili olduğu gösterilmektedir.

3 Gary Cross'un “Tüketilen Nostalji” (2018) kitabı bu yönüyle anlamlıdır. Cross kitabında batı kültüründe tipik nostalji nesneleri ve tüketim ilgisini ele alırken aynı zamanda kaybın ertelendiğini ifade eder. Nostaljinin tüketim
} 
Türkiye'nin modernleşme sürecinde kayıplar olduğu gibi günümüzde bunların dökümlerinin yapıldığı, yerlerine yeniden getirilmek, kayıplara neden olanlarla hesaplaşılmak istenildiği söylenilebilinir. Nostalji temsili bu açında kullanışlı görünmektedir. Bu çalışmada da toplumsal travma olarak görülebilecek darbe dönemlerinde geçen hikayeleri olan filmler ile nostalji perdesinin kuruluşu ve bu perdede travmatik olan ile hesaplaşma, en azından onunla nasıl karşı karşıya gelindiği soruları ele alınacaktır.

Bunun için belirlenen örnekler 2000 sonrası ana akım Türk sinemasından seçilmiştir. Bunun nedenlerini özetlemek gerekirse; (1) 2000 sonrası Türkiyessinde tek partinin iktidara gelmesiyle liberal politikaların hızlı görünür olması ve ifade özgürlüğü arasındaki doğru orantının söz konusu filmlerin artışında dolaylı bir etkide olması veya aynı düşünsel ve ifade dünyasında birbirlerini dolaylı şekilde beslemeleri. (2) Söz konusu filmlerin darbe ile ilgili özellikle 12 Eylül ile ilgili hesaplaşmanın konuşulmaya başlandığı veya bunun yaygınlaştığı zamanlarda üretilmiş olması. (3) Yine bu filmlerin bilinçli bir nostaljik anlatıma yer verirken söz konusu travmatik, dönüştürücü tarihsel olayları tarihsel arka plan veya özellikle etkileyici dış güç olarak bilinçli şekilde kullanmaları. (4) Söz konusu filmlerin ortak yapısal karakter göstermeleri.

Çalışma bu filmlerdeki yapısal ortaklıkları ve ifade düzleminde anlatısal ortaklık ve farkları ele alırken, temsiller açısından durum ve olayların, kimliklerin nasıl gösterildiğini anlatma amacındadır. Temel iddia ise nostalji temsilinin Türkiye sinemasında Yeşilçam tavrını izlerken bu tavrın içine tarihsel ve travmatik olayları gösterme amacında olması şeklinde özetlenebilir.

\section{Nostalji Perdesi ya da Modern Olmak}

Modern olmanın gücü ileriye doğru atılmış projelerin kahramanı olmanın hissedilmesidir. Bu projeleri anlamlı kılanın ileride insanlığı bekleyen hayat değil, bunun gerçekleşmesinde geçmişin ağırlıklarının azaltılması, geleneklerin ortadan kalkması, kuralların hafifletilmesi ve hatta bozulmasıdır. Modern bireyin ruh halinde bu yaratıcı yıkıcı kahraman imgesi melankolik ve kaygilı ruh halleriyle el ele gitmiştir. Çünkü geleceğe ait projelerin sahibi olan modern birey, geçmişi kaybettiğini, elinden bir şeylerin kaçtığını hissederken içten içe kendi anlam dünyasını nasıl kuracağı sorusuyla baş başa kalmıştır. Modernizm, parçalı bir dünya haritasıdır. Bu dünyada melankoli ve kaygı, kaybedilen ve şimdiki zaman içinde kişinin fragmanter deneyimler halinden nasıl bir anlam dünyası üretebileceğine işaret etmektedir (Frisby, 2012: 23-57, Sass, 2013, Simmel, 2003: 57-85).

Modernliğin romantik karakterindeki melankolik hal kaybın giderilmesi için uğraşılmasına işaret etmektedir. Romantik ruh hali, tek bir biçimi olmayan (Berlin, 2004: 1940) Romantizm'in elinde antik kültürden doğunun mistik ve otantik mekanlarına uzanan (Claudon, 2006: 14-17) geniş bir yok mekan içinde keşfedilmeyi bekleyen geçmişe ait olanlar ile melankolisini beslerken, yas tutmayı da ihmal etmemiştir. Romantizmin, modernizmin eleştirisinin anahtarı olmasında bu ruh halinin yattı̆̆ iddia edilebilir.

\footnotetext{
yönünün aynı zamanda postmodern toplumlarda bir deneyim imkanı olduğu konusunda Jean Baudrillard'ın "Tüketim Toplumu" (2018) önerilebilir. Baudrillard kitabında tüketim nesneleri kadar zaman ve mekan tüketimini, şimdinin ve geçmişin tüketimi de konu almaktadır. Yine tüketimi salt merkezine koymayan nostaljinin bellek ve geçmiş konusunda anlamlı olduğunu anlatan Svetlana Boyn'un "Nostaljinin Geleceği" (2009) kitabı önemlidir. Boyn kitabında komünizm sonrası Avrupa toplumlarında nostalji temasını ele alarak, travmatik olayın nasıl düzenlendiğini örnekleriyle göstermektedir.
} 
Derin bir özlem içinde olunan kayıp zaman ve mekan aynı zamanda deneyimin kaybına da işaret etmektedir (Jay, 2012: 386- 442). Nedir bu deneyim? Basitçe otantik olanın kaybıdır. Benliğe doğru yapılan keşif, isteyen ve eyleyen öznenin icat edilmesi ve bunun modernliğin koşulu olması beraberinde mutsuz bireylerin meydana getirildiği bir tarih sahnesi kurmuştur. Bu mutsuzluk, kelime dağarcı ğı olarak yabancılaşma (Marx), nevrotik (Freud), sürü insanı olma (Nietzsche), kitleselleşme (Frankfurt Okulu), tüketim toplumu halini alma gibi çeşitlilik gösteren, ortaklık olarak da söz konusu mutsuzluğa işaret eden anlamlar üretmiştir.

Deneyim kaybı, bir zamanlar var olan ilişkiler silsilesinin, teamüllerin, otantik olanın kaybıdır. Nostaljici tutumun zamanın düşünürlerinde istemsiz şekilde varlık göstermesinin altında yatanın modern deneyim dünyasının kültür ve bireye kazandıracaklarının kaybettirdiklerinden çok az olması veya anlamsız görünecek olmasıdır. Friedrich Nietzsche' den Martin Heidegger'e Yunanlı olmak, Marksist komünal yaşam, Jean Jacques Rousseau'dan Alman Ekspresyonistlere ilkel yaşam ve kültür övgüsü, Oryantalistlerin doğuya bakışlarında bulduklarına inandıkları otantiklik ve daha niceleri. Modernliğin düşünce ortamı nostaljici bir tutumun izlerini ister yoğun ister gizil olsun gösterirken çoğunlukla bunlar geleceğe atılmış projeler olarak ütopyacı modernizmin gelecek düşüne dönüşmüşlerdir.

Walter Benjamin'in "deneyimin metodik yıkımı" adını verdiği modernizm (akt. Jay, 2012: 386) nostaljik bir tutumun görünümünü içermektedir. Benjamin'in yarım kalmış projesinin altında yatan motivasyonlardan ve düşüncelerden birisi olarak deneyimin yeniden düşünülmesi, O'nu modernliğin nostaljici tutumunun örneklerinden olarak görmemize neden olmaktadır. Adorno'ya yazdığı mektupta Benjamin şunları söylemiştir:

"Deneyim teorimin" kökleri bir çocukluk anısına uzanıyor. Yaz aylarını geçirdiğimiz yerlerde, annem ve babam adet olduğu üzere bizi yürüyüşe götürürlerdi. Hep iki-üç çocuk olurduk. Ama benim aklımda en çok erkek kardeşim kalmış. Freudenstandt, Wengen ya da Scheiberhau civarındaki bir-iki mekanı mecburen ziyaret ettikten sonra kardeşim şöyle derdi: "Artık oradaydık diyebiliriz." Bu ifade adeta zihnime kazındı (Benjamin, akt. Jay, 2012: 387).

Benjamin'in şeyleşme karşısında, parıltılarda saklı hakikati keşfetme sanatı, modern kültürün meta dünyasının ideolojik mistifikasyonunda sanki bir kaza eseriymiş gibi duran sahici olanı elde etme amacı taşımaktadır. Benjamin'in bu tutumu nostalji temsilinin kolay tüketim nesnesi olmanın yanında kendi içinde belirtisel nitelikler taşıyor olduğu şeklinde de görülebilir. Bu aynı zamanda geçmişin şimdiyi meydana getirirken nasıl etkiler ürettiği konusunda da fikir verecektir.

Marcel Proust'un bellek sahnesi olan kayıp zaman serisi, yazarın kendi yaşamına bir bakış, kaybedilmiş anıların yeniden ele alınması ve belleğin kaydedici özelliğinin gösterimi değil, onun parçalı olduğunun göstermesiyle, parçaları bir araya getiren yazı işçiliğiyle Benjamin'in deneyim düşüncesine benzer şekilde ele alınmasında neden olmaktadır. Yazı ve dil, deneyimi yeniden inşa ederken, kaybedilmiş olanı yeniden yaşamak ve onu yeniden canlandırmak, nostaljinin eylemsiz görünen durumuna ters, üretici bir tavır olarak da görülmelidir. Bu açıdan yazı ve söz, seyrin hazzının verdiği mutluluk vaadine göre üretici bir tutum sergileyebilmektedir.

Deneyimi yeniden tesis etmek, yabancılaşmanın yıkıcı etkilerine karşı öznenin kendisini bulması demektir. Deneyim, bir zamana ait deneyim değildir. Öznenin kendi varoluşunu yaşamasıdır. Ancak modernitenin el ele gittiği meta kültürü, şeyleşme ve yabancılaşmayı 
olağan bir gündelik yaşam olarak yaymaya devam ederken, nostaljinin romantik tutumunu çocuksu bir bitmeyen isteğe dönüştürecektir.

Nostaljinin çoğu zaman kitsch benzeri bir estetik kategoriyle ilgisine karşıllık böyle bir ilgi içerdiğini öne sürmek gerekmektedir. İlk olarak nostaljinin romantik melankolinin bir tür görünümü olması dışında modern tüketim kültürünün esaslı bir parçası olması durumu karşımıza çıkmaktadır (Cross, 2018: 7-33). İkinci olarak kitsch, sanatsal kategorilerin taklidi olduğu kadar onların yüzeyde gezer hale getirilmesidir. Kitsch estetiği sahici olanı taklit etme derdinde değildir. Gerçeklik temsili, fotoğrafik üretime benzer bir biçimsel düzen amaçlarken içerik yüzeyde gezer bir duygusallık ile anlam kazanır (Calinescu, 2010: 251-280). Bu duygusallık ise nostaljinin içerdiği duygusallığa benzemektedir (Calinescu, 2010: 262).

Nostalji imkansız olana işaret eder. İster tüketim ister kişinin kendiliği konusunda bir arayışı olsun nostaljik bir deneyim aslında bir tür parantez açmak demektir. Kelimenin yunanca karşılığında nostos (dönüş) ile algos (acı) kelimelerinin yan yana geldiği görülmektedir. Kelime, "geri dönüş acısıdır", uzakta olmanın hissedildiğindeki acı ile geriye dönüş sırasında hissedilen acı (Cassin, 2018: 16). Hissedilen acı neyin acısıdır? Kendisine ulaşılanın aslında onun o olmadığını görmenin acısıdır. Geçmişte kalan ile kişinin içindeki geçmiş arasında bir farkın olmasıdır. Bu farkın gücü geri dönüş isteğindeki kişinin orada bulacağı ve kendisini bütünleyeceği arzu nesnesi haline getirdiği bir parçanın aslında orada olmadığını görmesinde saklıdır. Bu acıyı hafifletmek için ise imgeler devreye girmektedir.

İmgeler sadece modelin yansıması onun kopyası değildirler. İmgeler namevcut olanı mevcut hale getirmektedirler ${ }^{4}$. Sinema tarihini aygıtın gelişimi açısından teknik bir başarı, sektörün varlık bulması ve gelişmesi açısından sanatsal ve kültürel bir başarı olarak okumak mümkün olsa bile kaçınılmaz olan, sinematik imgenin kaybedilmiş olanı yakalama, gösterme imkanına ve gücüne sahip olmasıdır.

\section{Rüya Sahnesi ve Nostalji}

Sinema ile nostalji duygusu arasında tarihsel bir paralellik kurulabilir. Her ikisi de modern olgulardır. On dokuzuncu yüzyıl sonlarına doğru modernitesinde yanılsamanın yeni görünümü, hareket imge olacaktır. Bu sadece resim ile sinema arasındaki kesin farkı göstermez. Görmeye dair olduğu kadar belleğe dair düşüncenin değişimini de göstermektedir (Crary, 2004: 13-38). Sinema imgesi, belleğin depolayıcı gücüne sahip görünecektir.

Sinema, hareket eden imgeler geçidini sunarken, izleyici gerçekliğe biraz daha yaklaşmıştır. Yanılsamanın biçimsel ortaklığında benzerliğin modelin yansısını ele geçirmek olmasına karşılık sinema, hareketi ele geçirerek modelin donuk imgesinin bir öteye taşımıştır (Arnheim, 2002: 14,15). Poz veren dünya, fotoğrafın elinde varlığını sürdürürken, sinema aygıtı ile dünyanın hareketinin benzeri çıkartılmış ve bir başka dünya simülakrumu ortaya çıkmıştır (Pezzella, 2006: 28-30). Soluk bir dünya imgesi olsa da sinemanın ilk zamanlarındaki çatallaşma aynı zamandan teorik bir yarılmanın ilk belirtilerini ve günümüzde bile güncelliğini koruyan bir ikiliğin varlık gösterdiği görülmektedir. Bu kurgu ile gerçek arasında ki yarılmadır.

Sinema tarihi bu yarılmanın başlangıç olmasıyla hareket etmeye başlamıştır. Lumiere'lere karşı Melies. Fabrika çıkışında insanların gösterimine karşılık "Ay’a Seyahat"

4 Bu konuda Zeynep Sayın'ın “İmgelerin Pornografisi” adlı eserine bakılabilir. Sayın imgelerin işlevi konusunda farklı dönemlerden imge düşünceleri ve üretimlerini anlattığı eserinde imgenin hatırlatıcı gücü konusunda da teorik ve olgusal çözümlemelere gitmektedir (Sayın, 2003). 
(Armes, 2011: 22-31). Sinema aygıtının gerçeklik karşısında katı gösterimi, yanılsamayı kolaylıkla elde edebilen aygitın sürekli gelişiminde aranmamalıdır. Siyah beyaz ve sessiz imgelerden günümüz dijital imgelere gerçekliği taklit etme sinemanın başarısı değildir. Sinema gerçekliği kurar. Taklit etme, gerçekliğin kendi başına halini göstermek anlamına gelmez sadece. Taklit etme gerçekliğin işleyişine benzer şekilde bir başka gerçeklik üretmektir. Hareket ve zamanın taklidi yaşantımızın eş benzerini üretme konusunda sinema imgesinin gücüdür. Zaman içinde varlık bulan sinema imgesi, bizler gibi hareket etmektedir. Bizler gibi konuşur, yaşlanır ve çatışır gibidir. Sinema gerçekliği, bu açıdan çarpıcıdır.

Aynadaki imgenin gücü poz vermede, donuk hale gelmesinde saklıdır. Batı klasik resminin gücü gibi. Dondurulmuş ve idealize edilmiş bir yüz, poz veren beden daima yaşayacaktır. Sinema imgesi ise yaşantıya rakip olacak şekilde varlık göstermektedir. Sinema imgesi gerçeklik algımıza müdahale edebilmektedir (Koolker, 2010: 27).

Medya çalışmalarının ana ekseninde yer alan dezenformasyon olgusu bunu örneklemektedir. Kurgu, imgeleri dönüştürerek, olayların algılanmasında izleyeni saran bir gerçeklik meydana getirebilmektedir. Haber bültenlerinden sosyal medyaya, izlenilen kimi videoların meydana getirdiği gerçeklik duygusunun, kandırmaca olduğu kanıtlansa bile izi kolaylıkla silinememektedir. Kurgu, sinema imgesinin gerçeklik tutumunu dönüştüren unsurdur. Aygıtın gerçekliği gösterme tarzındaki doğruculuğu değildir. Bu yüzden sinema rüya benzeri bir özelliği sahiptir. Rüyalar imkansız kurgulamalar içeren hareket imgeleriyle rüya göreni içine alan özellikler göstermektedirler. Roman anlatıcısı gibi rüyalar tepeden izlenebilirler. Sinema perdesinin yüz yılı aşkın vaad ettikleri de buna benzemektedir.

Günümüz sanal gerçeklik tutkusunun sinema perdesine dahil olması, rüya sahnesinin artırılmış gerçeklik ile dengelenerek güçlendirilmesi, izleyenin bir şeyleri unutmasını sağlaması şeklinde yorumlanmaya müsaittir. Daha doğrusu unutma bir tür belleği düzenleme ile ilgilidir. Proust'un bellek çalışması olarak görülebilecek seri romanları gibi (Deleuze, 2004: 11-13). Proust, tıpkı sinema gibi kalıntı imgeleri bir araya getirerek geçmişi anlatmaktadır. Her anlatım yeniden icat etmedir. Geçmiş icat edilir. İcat edilen olayların meydana getirdiği fikirler ve duygular olmaktadir.

Psikanalizde konuşma kürüne gelen kişinin uzmanla konuşmasında semptomlarını söylemesi aynı zamanda onları kurması, yeniden düzenlemesidir. Bir rüyasını anlatan kişi, kaçınılmaz olarak önem sırasına, hatırlama oranına, bastırmanın etkilerine, kısaca seçmeler ve birleştirmeler ile anlatmaktadır. Dile karşı görüntülerin ontolojik farklılığı göz ardı edilemese de sinema imgelerinin bil benzeri bir seçme ve birleştirme ile bir konuşma meydana getirdiği söylenebilir.

Sinemanın rüya sahnesinin eleştiri boyutu onun izleyiciyi bitimsiz bir uykuya hapsetmesi şeklindedir. Sanki bir mağarada izlenilen gölgelere inanan insanlar gibi sinema izleyici de kurgunun cazibesiyle yaşantıyı unutur hale getirilmektedirler. Ancak düşünülmesi gereken sinemanın gerçeklik duygusunu nasıl ürettiğidir? Zaman ve mekan deneyimini nasıl meydana getirdiğidir? Bunun en sıradan örneğinin sanat sinemasının popüler ana akım sinemaya göre zaman ve mekan deneyiminin yavaş ve ağır hale getirdiğinde izleyicide meydana getirdiği sıkıntı halidir. Estetik düzeyde seyri kolay bir hazzı sunmayan, yaşantıya benzeyen bir zaman mekan düzeninin kendisinde uyandırdığı hoşnutsuzluk aynı zamanda gerçeklik algısında meydana gelen kırılmayı göstermektedir. 
Her iki sinema dilinin ise gerçeklik ve rüya karşıtlığı içinde düşünülmesinin hatalı olabileceği önerilebilir. Rüya yanlış yola sevk edilmenin karşılığı olarak görülmemelidir. Rüya üretici bir tavır almanın, ütopyanın veya eleştirel tutumunda imkanıdır (Botz-Bornstein, 2011). Rüya deneyimi, gerçekliği düzenleme imkanı da meydana getirmektir. Öyle ki bilinçli düşünmenin düzenleyici berraklığı karşısında rüya deneyiminde öznenin merkezde olamaması kendiliğinden bir araya getirme halinin yaşanması olarak anlamlı görülecek bir başka düşünme durumunu sunmaktadır. Nostalji, rüya benzeri özelliğini ise önceden verili olan bir fantezinin gerçekleştirilmesi ve bir şeylerin üzerinin örtülme çabasının ağırlıklı olmasında kendisini göstermektedir. Nostalji ve rüya ilişkisi fantezide ortaklık kazanmaktadır.

Rüya sahnesi hayal edilene yolculuk olmasıyla sinemanın bitmeyecek gücünü içinde saklamaktadır. Popüler veya kitle sineması için düşünülebilecek "rüya sineması" ifadesi gerçekliği unutturan bir anlayışı gösterse de başka bir bellek gösterimini öne sürmekten kendisini alıkoyamayacaktır. Nostalji temsili de unutma halini aza indirgeyen bir hatırlama tutkusunu, travmatik olanı perdeleyen mekanizmasıyla gerçekleştirmesiyle buna örnektir.

Nostalji, melankoli ve yas ilgileri içinde kaybın yerine konulacak bir şeyi bulmak, böylelikle melankoliden kurtularak yas tutmayı sağlamaktır (Freud, 2002: 243). Sinemanın nostalji temsilinin yası, haz alınır hale getirmesi, onu en azından hayıflanmaya dönüştürmesi mümkün görünmektedir. Söz konusu yas olduğunda ondan haz almak varoluşumuz için gereklidir. Çünkü yasın yerine geçecek melankoli benliğin yitimi ve tümüyle gerçeklik içinde konumsuz kalan bir yaşantı anlamina gelecektir (Freud, 2002: 257). Burada izleyici için deneyim imkanları ve yorumlama çeşitliliği devreye girecektir. Yorumlama özgürlüğüne sahip olduğuna inanılan izleyicinin konumunu temsillerin gücü açısından dengelemek de gerekecektir. Travmatik bir içeriğin biçimselliği ona yakınlaşma olduğu sürece imgenin pornografikleşmesi ve değerler açısından düşünümsel bir tavır almaya engel olabilmektedir Bu çalışma kapsamında güldürü ve melodram türü içinde kalan örnekler tipikleştirmeler ile mesafe koyarak izleyici için bir imkan sunabilirler. Bu imkanın ise düşünme açısından derinlik olmasını beklemek tipleştirme ve yapısal ilişkiler (iyi/kötü, doğru/yanlış, iktidar/mazlum...) nedeniyle zor görünebilir. Tipileştirilmiş olaylar ve karakterler empati kurmayı kolaylaştırırken eleştirel olanı, istem dışı veya derinlikli bir düşünmeyle gerçekleştiremeyecektir ${ }^{5}$.

Sinemanın imgeleri rüyaya dönüşmekten kaçamayacağı için nostalji benzeri bir konumda kendisini bulmasını da olağandır. Sinema, kurgu ile hareket ve zaman ilgilerinin belli bir mantık düzeyine çekse bile olası bir dünyanın yansımasını sunarken onun imkansız dünyalardan birisi olduğunu söylemeyi ihmal etmemektedir. İşte bu fantezinin ana özelliğidir. Fantezi gerçekleştirilmesi istenilen ancak gerçekleşemeyecek olandır. Bu karakteri de fantezimim ömrünü sürekli kılmaktadır (Zizek, 2004: 17). Özne fanteziyi gerçekleştirirse arzulama da nihayete erecektir. Ancak bu mümkün değildir. Sinemanın rüya boyutu da bu imkansızlığı vurgulamakta ve ikame nesneler üretmektedir.

Nostalji de bu açıdan ikame imgeler ile travmayı hafifletmektedir. Travmatik olan her zaman perdelenmek zorundadır. İmgeler ise bunu gerçekleştirme iddiasından vaz geçemezler. Sürekli tekrar eden imgeler dizisini veya travmatik anı canlandırma konusunda topyekun seferber olmuş imgeleri düşünelim. Olayın ta kendisini verme iddiası için tekrar etmek ve canlandırmak olayın etki gücünün çoktan kaçırıldığını göz ardı etmektir (Zizek, 2003: 13-21).

5 Bu noktada izleyici tutumundan ziyade temsilini kendisini işleyişinin çalışmanın ana ilgisi olduğu göz ardı edilmemelidir. Temsiller ürettiği izleme edimleriyle izleyici pozisyonunu içlerinde önermektedirler. 
Darbe dönemlerindeki şiddet, gölgelere, duvar boyamalarına dönüştüğünde travmatik boyut perdelenmişolunur. Sinema perdeler. Göstermenin zor olduğunu bilmesiyle perdelemeyi tercih etmek durumunda kalmaktadır. Doğrudan göstermek, işkenceyi empati ilişkisini aşar şekilde hissettirmek mesafenin azaldığını düşündürtmektedir. Ancak mesafe her zaman olacaktır. Bu sinemanın ontolojik karakteridir. Gaspar Noe gibi yönetmenler veya Dogma gibi akımlar bu gösterimi arzulamalarıyla sinemanın kıyısına geldiklerini düşündürtebilirler. $\mathrm{Bu}$ tavırlar perdeye yapılan estetik anlamda yatırımları bozmaktadırlar. Bu örneklerde sinemanın kitle sanatı halini almasina neden olan seyir hazzi ${ }^{6}$ azaltılır. Yine de perde mesafe koymak zorundadır. Kendinden menkul varoluşu izleyicinin kendisiyle kurması gereken mesafeden itibaren başlayan bir uzaklık ve güvence içermektedir. Dolayısıyla katı gerçeklik bir süre sonra pornografik düzeyde olsa bile fantezi boyutuna varmak zorunda kalacaktır.

Nostalji temsilinde zihni etkileme ve geçmişi hatırlatma konusunda bitmeyen bir rüya sunma arzusu söz konusudur. Bu nostalji temsilinin ideolojik bir sorun olarak görünmesinin de nedenidir. Ancak rüya olma arzusu üretim olarak bir başka bakış açısı meydana getirebilir. Bu teorik olmaktan çok sinematografik bir yaklaşım öne sürmeyi şart koşmaktadır.

2000 sonrası Türkiye sinemasında nostaljinin pozisyonu Yeşilçam kalıplarından beslenen ve onun üzerinde yükselen bir tutum göstermektedir. Yeşilçam sinemasının geçmişi hatırlama konusunda darbelerin, sınıfsal çatışmaların, hakların ve olayların yargılanmasının karşısında güvenli geçmiş seyri sunması problemli olmuştur. Yeşilçam, rüya sineması tavrını sürdürmeyi tercih etmiştir. Ürettiği kalıplar ve en önemlisi estetik beğeni yeni sinemanın kullanacağı kalıpları kendisine sağlamıştır. En önemlisi ise Yeşilçam'ın kendisinin nostalji temsilini üretmesidir. Ancak bu Türkiye'nin darbe sonrası normalleşme döneminde, yeni Yeşilçam’ın bittiği yeni bir alımlamayla yorumlanacağı 1990'ların televizyon kanallarında gerçekleşecektir.

\section{Televizyondaki Yeşilçam}

90’11 yılların Türkiye'sinde liberalizm dalgası, beraberinde kültürel değişimi de getirmiştir. Dünya genelinde soğuk savaşın bitmesiyle hızlanan küreselleşme bu kültürün dağılımı ve yayılımını daha etkili kılmıştır. 12 Eylül 1980 darbesinden sonra gelen Özal dönemi ile birlikte liberalizm, her alanda dolaşım özgürlüğü iddiasında olurken serbest girişim hızlanmıştır. Sinema, 12 Eylül'den her türlü anlamda etkilenirken, giderek artacak olan televizyon kanallarının da Yeşilçam sinemasını başka bir kuşak ile buluşturarak hem bu durgunluğu kesinleştirecek hem de yeni bir alımlama meydana getirecekti ${ }^{7}$. Yeşilçam sinemasının, 90'lı yıllarda özellikle Eşkiya (Yavuz Turgul, 1996) filmine kadar sinema salonlarında etkili ve güçlü bir yer bulamaması, televizyon ekranlarında sıkışması bu dönemin

6 Çalışmada geçen haz kelimesi izleyicinin sinema filminden aldığı haz olarak kendisinde uyanan duygusal bir boşalım şeklinde düşünülebilinir. Bu seyir ve haz ilgisi içinden eğlence ve tüketim şeklinde anlaşılabilinir. Ancak hazza dair bakış açısı ne olursa olsun, haz mutluluğa dairdir. Onu üretici kılacak olanın ise eylem ile ilgisi içinde bir dönüşüm olması gerekmektedir. Bunun için ise sanatsal temsiller kadar izleyicisinin kendi varlığına dair temsillerin üretici konuma getirilmesi gerekmektedir. Bu ise politik ve kültürel pozisyonların düşünülmesini şart koşmaktadır.

7 Bu kısımdaki iddiaları spekülatif düzeyde okumak mümkündür. Söz konusu değişim hakkında aygıtın dönüştürücü gücü, dönemin bakış açısı ve kültürel dünyası açısından Yeşilçam>ın dönüşümü konusu detaylı bir çalışma için sonraya bırakılmıştır. Ancak bu çalışmadaki yeri önemlidir. Çünkü bu dönüşüm yeni bir izleyici kitlesi anlamına gelirken ana akım Türkiye sineması için bir kalıp sunması açısından Yeşilçam'ın yeni alımlaması dikkate alınmalıdır. Bu nedenle kimi yerlerdeki tartışmalı noktaların üretici düzeyde anlamlı görünmesi daha uygun olacaktır. 
Türk sinemasının içinde bulunduğu koşulların bir özeti olarak okunabilir8

Televizyon kanallarının Yeşilçam sinemasını her gün farklı saatlerde ve özellikle prime time diye bilinen akşam saatinde sürekli yayınlaması, Yeşilçam'ın melodram ve komedi tarzlarının yaşamasına ve hatırlanmasına hem de bu tarzların temsil ettiği dönemin bir belgesi ve en önemlisi kaybedilmiş bir deneyim zamanı içermesiyle alımlanmasına neden olduğu söylenebilir.

Mahalle mekanında toplumun en küçük çekirdek birimi ailenin otantik yuva temsilleri mahalleye kadar yayılan temiz bir dünya ve bu dünyanın kurallarının çıkarsız ve kendiliğinden ilişkiler ağı içinde şekil kazanması, Yeşilçam'ın televizyondaki seyrinde bir döneme özellikle 12 Eylül öncesi anarşinin içinde ‘saf kalan' bir dünyayı izleyicisinin önüne çıkartmıştır. Her ne kadar mahalle kültürü 80'li yıllarda özellikle Atıf Yılmaz gibi yönetmenlerin filmlerinde birey olmanın engeli, dedikodu söyleminin kişiyi sıkıştırması olarak yorumlanmışsa da 12 Eylül öncesi Türk aile ve mahalle temsillerinin kaybedilmiş dönem ve ruh hali şeklinde gösterimi popülerliğini korumuştur.

Melodram ve komedi filmleriyle Yeşilçam, çok seyredilir saatlerde her gün ve defalarca izleyicisine sunulurken, televizyon dizilerinin sıkça kullandığı mahalle ve aile saflığ 190 'l1 y1lların dizilerinde kendisini gösterecektir. 80'li yıllar TRT'sinde Perihan Abla dizisinden 90'l1 yılların popüler dizilerinden Mahallenin Muhtarları'na kadar bu kalıp mahallenin yüceltildiği ve ailenin kutsandığı anlatılar olarak gerçeklikten bir kaçış olarak yorumlanabilir ${ }^{9}$. Nostalji temsiliyle geçmişi şimdiki zamanın Türkiye'sine taşıyarak izleyicisine rüya sahnesi sunan bu diziler, gündelik olaylara dair eleştirel bir tutum içerir gibi dursalar da genel eğilimleri gerçekliği ekranda göstermemek olduğu söylenebilir. Bu açıdan liberalizmin medya ve görsel kültüründe, enformasyon ile beraber estetize edilmiş bir geçmiş, neden kaybedildiği düşünülmeden seyre sokulmakta, tüketilmekteydi. Geçmişte kalan bir tavırlar dizisi, kimi jestler ve mimikler veya kelimeleri sinema perdesinde görmek izleyici için içinde yaşadığ zamana taşıyabileceği kimi parçaları bulduğunu düşündürtebilir. Yeşilçam sinemasının 90'lar alımlamasında olduğu gibi. Ancak bu büyüleyici fragmanları bir araya getirecek, onları organikleştirecek olanın ne olduğu sorusu bu dönemin görsel kültüründe sskalandığı kolaylıkla söylenebilir.

Popüler sinemada karakterizasyon yerine tiplemelere gitmek, sinematografi olarak güçsüz olabilecek karakterler meydana getirmek anlamına gelebilmektedir. İdeolojik çerçevelemenin burada devreye kolaylıkla sokulabilir. Tiplemeyle birlikte toplumun belli kesimine ve kimliklerine bakış kısıtlı hale getirilmekte, sınırlı bir bakış ile ötekileştirici mekanizmalar kolaylıkla devreye sokulabilmektedir ${ }^{10}$. Georg Simmel'in tipler sosyolojisi açısından sinema tiplemeleri, karikatürize edilmiş şablon karakterler olsalar bile bir

8 Eşkiya filmi, Yavuz Turgul sinemasında nostalji teması açısından da ele alınabilir. Bu konuda Halim Esen ve Vakur Kayador'un "Yavuz Turgul Sinemasında Nostalji" (2009) bakılabilir. Turgul sinemasında nostaljinin bir kalıp olarak kullanılarak derdini anlatma aracı şeklinde görülmesi önerilebilir. Bu açıdan Turgul'un sinemasının 2000 sonrası sinema ile bu açıdan benzerlik taşıdığı iddia edilebilir.

9 Bu kalıbın en son bilinene temsilcilerinden bir tanesinin Ekmek Teknesi (2002-2005) dizisi olduğu söylenebilir. Bu dizide de mahalle mekanı ve aile ortamı asıl kılınmaktadır. Diğer taraftan dizinin bir yönüyle gelenekselliğe dair göstergeleri benzeri öncül dizilere göre daha baskın kılması göze gelmektedir.

10 Bunun en tipik örneğini Çocuklar Duymasın dizisinde görebiliriz. Dizinin ana ekseninde baba ve annenin zıtlıkları maçoluk/geleneksellik ve feminizm/liberallik şeklinde meydana getirilmiştir. Bu aynı zamanda belli kimliklere karşı küçük gören ve ötekileştiren bir bakışın dizinin mizahi dilinin ana karakteri olmasını sağlamanın da yolu olmuştur. 
dönemin imgesini sunmalarıyla önemlidirler ${ }^{11}$. 12 Eylül öncesinin mahalle sakinlerinin saf ve kirlenmemiş dünyalarında görülebilecek baba figürünün (en tipik örneğinin Münir Özkul'un Yaşar Usta'sı olduğu söylenebilir) işçi sınıfı temsili olarak görülmesi abartılı olmayacaktır. Bir patron veya para babası karşısında değerlerinin satmamış ve onları korumanın erdeminde olan bir figür olarak baba figürünün emek ve ahlaki değer ilişkisinde aile hayatını dinsel değil de seküler şekilde ahlak odaklı kurguladığı söylenebilir ${ }^{12}$.

İdeolojik gösterim açısında Yeşilçam, dönemsel gerçeklere dolaylı bakan, onlarla mesafeli ve onların etkilerini hafifleten veya güçlendiren bir seçmeciliğe sahip görünse de kaçınılmaz olarak bir tür gerçeklik üretimine katkıda bulunmuştur. Yeşilçam'ın ideolojik boyutu, sektörün iktidar tarafından kontrol altına alınması, doğallaştırılmış ön kontroller ile senaryoların kırpılması ve değiştirilmesi açısından tanımlanabilir. Sansür mekanizması üzerinden Yeşilçam'ın zorunlu ideolojik angajmanının yanında ana akım sinema kuralları ve kimi anlatıları tekrar etmesiyle de söz konusu olan ideolojik boyutu kendisi de üretmiştir. Popüler sinemanın komedi, melodram, aşk filmlerinde kullana geldiği temalar ve yapısal düzen, Yeşilçam'ın da sevdiği ve tekrar ettiği temalar olurken; bunlar bir süre sonra da kendi kurallarının oluşmasına da yardımcı olmuştur. Dönemsel temsiller açısından Yeşilçam'ın söz konusu türler ve konuları ele alan filmlerinin bir şeyleri gösterme amacında olduğu da göz ardi edilemez.

Temsillerin yanıltıcı olduklarını düşünmek olağandır. Nihayetinde temsiller bir tür çerçeveleme ve bakış açısı ürünüdürler. Bu sebepten ötürü bir görüşün üreticisi oldukları gibi bir görüşe angaje de olurlar. Ancak gösterim tarzı, belirtiler dizisi olarak gerçekliğe karşı tutumun ona karşı tavrın veya onu anlatma karakterine de sahiptir. Bu yüzden Yeşilçam sinemasının tipler etrafından 2000'li yıllarda sosyolog Şerif Mardin ile anılan mahalle baskısı kavramını önceleyen bir mahalle nostaljisi ürettiği iddia edilebilir ${ }^{13}$. 90'ların mahallesinde şiddetin, yabancılaşmanın, terörün kol gezdiği düşünülürse, televizyonda Yeşilçam anlatılarının kaybedilmiş bir geçmişin anlatısı olduğuna inanmak kolay görünecektir ${ }^{14}$. Yeşilçam, 12 Eylül öncesi döneme işaret etmektedir. Bu dönemin Türkiye'sindeki ahlaki anlamda huzurlu, aile ölçeğinde şekil kazanmış mahallenin ve kişiler arasındaki ailede görülebilecek ilişkiler ağının bozulması darbe ile gerçekleşmiş gibidir. 90'l yılların televizyon dizilerinde de mahallenin ana mekan olması dikkate değerdir. Perihan Abla, Mahallenin Muhtarları, Süper Baba gibi dönemin popüler dizileri Yeşilçam komedi ve romantik film kalıplarının sanki devamcısı olmuşlardır. 2000 'ler ile birlikte ise yeni bir dönem başlayacaktır. Bu dönem mahallenin yeniden ele alındı $\breve{g}$, sinemanın ise geçmiş ile olan ilişkileri yeniden düşünme isteğinde olduğu bir dönem olarak kendisini gösterecektir.

11 Bu konuda Ulus Baker'in çalışması anılmaya değerdir. Baker, Simmel'in tipler düşüncesi konusunda olumlu ve üretici bir konum olduğunu yazar (Baker, 2010: 50). Elbette bu olumlu durum dizi ve sinema ekranlarındaki tiplemelerin kısıtlayıcı ve ideolojik angajmanlarıyla oldukça zora giren bir ilişki anlamına gelecektir. Yine de tiplemenin sosyolojik bir okuma imkanı verdiği ve temsil ettiği görüşü ortaya çıkarttı̆̆ı kadar tiplemeye ait ifade düzlemini anlama konusunda veriler sunduğu ve üretici boşluklar içerdiği iddia edilebilir.

12 Böyle bir okuma içinde Yeşilçam»ın mesafeli olduğu bir sınıfı kaçınılmaz olarak düşündügü görülebilir. Günümüz popüler Türk sinemasında ise böyle bir yaklaşımı görmek ise zordur. Recep İvedik karakteri buna iyi bir örnektir. İvedik, öncülü olan İnek Şaban gibi karakterlerin devamında bir sınıfın veya ortamın tipi değil gibidir. $\mathrm{O}$ daha çok semptomatik bir yapıdadır. Kabalık ve bedensel anlamda yakınlık kurabilmesini belirtiler düzeyinde anlamlandırabiliriz. Buna göre İvedik, sınıfsız kalmış mahallesi olmayan bir karakterdir. Seri filmlerinde ana sorun bir yere konumlanmak, yerleşmek olması da buna örnek gibi görünmektedir.

13 Kavramın ortaya çıkışı ve tarihsel seyri konusunda Adnan Çetin'in “Bir Kavramın Kısa Tarihi: 'Mahalle Baskıs'"' (2010) adlı yazıya bakılabilir.

14 90'lı yılların Türkiye'sinin bu konuda dökümü için Ali Yılmaz'ın “Karanlık Vardiya 90'lı Yılların Politik Arşivi” çalışması önerilebilir (2015). 


\section{Yeni Türk Sineması'nda Nostalji Temsili}

Yeni Türk sineması ifadesi, 2000 sonrası Türkiye'sinde sinemanın geçirdiği değiş̧imlere işaret etmesi adına kullanılmaya başlanmıştır. Asuman Suner, "Hayalet Ev" adlı çalışmasında Yeni Türk sinemasını çerçevesini şu şekilde çizmektedir:

Yeni Türk sinemasının ortaya çıkışını birbirine koşut gelişen iki düzlemde tanımlamak mümkün: Bir yanda büyük bütçeli, yıldız oyuncu ve/veya yönetmenleri öne çıkaran, vizyona girmeden önce medyada yoğun bir reklam/tanıtım kampanyasıyla adından söz ettirmeye başlayan, geniş dağıtım/ gösterim olanaklarına sahip ve gişede başarılı hasılat yapan bir «popüler» sinema; diğer yandaysa yönetmenin bir bütün olarak filmin yaratım sürecine damgasın vurduğu, küçük bütçeli, çoğu kez amatör ve/veya tanınmamış oyuncuları kullanan, Türkiye'de sınırlı dağıtım ve gösterim olanağı bulan, ancak ulusal ve uluslararası festivallerde gördüğü ilgi ve kazandığı prestijli ödüllerle kendinden söz ettiren bir "sanat" sineması... (Suner, 2006: 33).

Yeni Türk sinemasını endüstri düzeyinde anlamlandıran bu tanımlama, görünür şekilde kesintiye uğramış sinemanın yeniden harekete geçtiğini söylemektedir. 90’lı yıllar sinema salonlarında ağırlıklı olan yabancı filmler karşısında kendisine televizyonda yer bulmuş Türk sineması, 2000'li yıllarla birlikte harekete geçerken Suner'in ifade ettiği endüstri düzeni boyutunda anlam kazanmamıştır. Söz konusu değişimler, endüstri düzeyinde olduğu gibi sinematografik açıdan da bir dönüşüme işaret etmektedir.

Yeni Türk sinemasında karşımıza çıkan nostalji temsilinin Yeşilçam sinemasıyla bağı kurulabilir. Genel anlamda sinema sanatının ilk dönemlerinden bu yana anlatısal düzendeki tipleme, olay örgüsünü akışkanlığını kolaylaştıran ilişkiler boyutu, müzik ve görselliğin kullanımı gibi durumların meydana getirdiği rüya sahnesi veya masalsılık ile nostalji temsili arasında organik bir bağ vardır. Gösterilen iki dünyanın da aseptik ve korunaklı, yabancılaşma öncesi organik bir toplum oldukları görülmektedir.

Yeşilçam sinemasının, arka planda almış olduğu Hollywood başta olmak üzere diğer ülke sinemasında görünen hikaye ve kalıpları çokça kullanması ve kendi biçemini meydana getirmesi, rüya sahnesi olarak Yeşilçam sinemasının nostaljik temsili meydana getirme konusunda kaynak olmasına da neden olmuştur. Diğer taraftan, Yeni Türk sinemasının yönetmen ve yazar kuşağının bu sinema ile buluştuğu, büyüdüğü de göz ardı edilemez. Yeşilçam'ın 90'lar televizyonunda yeniden üretilmesi aynı zamanda görsel kültürde 90>larda Yeşilçam'ın popüler ve ana akım örneklerinin bolca tüketilmesi anlamına gelmektedir. Bu açıdan görsel bir hafıza ve anlatı kalıbı olarak Yeşilçam sinemasındaki melodram, aile filmleri ve komedi filmleri nostalji sinemasının da kalıplarının belirlenmesinde nerdeyse kanonik bir görev görmüştür. Bu durumda çalışma kapsamında belli açılardan ele alınacak olan filmlerin görsel ve anlatısal kalıpları bir dönemin tarihsel algılamasının hazır olarak Yeşilçam'dan almasıyla gerçekleştiği söylenebilir. Bu durumda tarihselliğin devreden çıktığı bir anlatısal ortaklık ile Yeni Türk sinemasında nostalji temsilini anlamlı kıldığı iddia edilebilir.

2000 sonrası nostalji temsilini kullanan filmlerde ortak kimi noktaların, yapısal düzenlerini ortaya çıkartmak, söz konusu filmleri ele alırken kolay ve genel geçer bir perspektif sunmak adına önemli olacaktır. Bu çalışma kapsamında odaklanılan film örneklerindeki yapısal benzerlikleri şu şekilde sıralamak mümkündür: (1) Küçük bir kasaba, mahalle veya köyde geçmeleri, bir mikro evren olarak bu mekan karakterinin asıl olması, (2) buna uygun 
şekilde ilişkilerin aile içi ilişkilerdeki gibi, yabancılığın olmadığı bir yakınlık ve kendiliğinden bir kurallar dizgesiyle güvence altına alınması, (3) bu saf ve otantik ilişki dünyasının dışarıdan, özellikle devlet eliyle gelen, bir müdahale ile bozulması ve artık hiçbir şeyin eskisi gibi olmayacağı, (4) bu olayın travmatik bir etkide bulunması, ancak bunun etkilerinin görünür şekilde gösterilmemesi.

Filmleri sahne sahne incelemek yerine bu yapısal ortaklıklar dahilinde ele alma amacındayız. Söz konusu filmler Propaganda (Sinan Çetin, 1999)15, Vizontele (Yılmaz Erdoğan, Ömer Faruk Sorak, 2011), Vizontele Tuuba (Yılmaz Erdoğan, 2003), Beynelminel (Sırrı Süreya Önder, Muharrem Gülmez, 2006), Şellale (Semih Aslanyürek, 2001), Babam ve Oğlum (Çağan Irmak, $2005)^{16}$. Bu filmlerin Yeşilçam'dan ödünç aldıkları bir estetik boyutun olduğunu bunun ise nostalji ile anlam kazandığı iddia edilebilir.

Nostalji temsili mikro bir evreni, toplumun küçük bir birimi olarak aileyi ve mahalle mekanını (buna kasaba ve köy de eklenebilir) ana unsur olarak göstermektedir ${ }^{17}$. Bu yok yer, aslında kaybedilmiş bir masumiyetin simgesi olduğu gibi, filmde de masumiyeti kaybolacak bir yerdir. Bu yerin dişarısıyla kurduğu keskin ayrım, onun kendisine yeten bir düzene sahip olduğunu göstermektedir. Sınır ile iktidardan kendisini koruyan bu yer için söz konusu mesafe bilinçli bir tercih değildir. Bu yer tipleri genel olarak mahalle, köy veya kasabadır. Dolayısıyla da merkezden uzaktır. Aynı zamanda iletişim aygıtları ve yol gibi ulaşım imkanları dönemin koşulları nedeniyle yaygın olmaması bu uzaklık duygusunu daha da güçlendirmektedir.

Uzaklığı nedeniyle iktidar mekanizmalarının bürokratik düzenleyiciliği veya askeri kuralcılığı buralarda kendisini gösteremez. Propaganda, Vizontele, Vizontele Tuuba, Beynelminel, Şellale buna eklenebilecek Hükümet Kadın (Sermiyan Midyat, 2013) bir zamanların dünyasından bir parçayı, kaybedilmiş toplumsal ilişkilerdeki kendiliğindenliğin gösterileridirler. Taşra hayatının kent hayatına göre ilişkileri yabancı hale getirmemesi, masalsı denilebilecek olan ilişkileri ve toplumsal düzen anlatısını da gerçekçi kılmakta, bu etkiyle nostalji temsili güçlendirilmektedir.

Nostalji temsilinde toplumsal düzen kişiler arası ilişkilerin aile içi benzeri bir doğallıkla şekil kazanmasıyla karakterini kazanmaktadır. Bu nostalji arzusunun ana unsurudur. Modern nostalji duygusunun kentleşme ve yabancılaşma karşısında otantik toplumsal bağ tasavvuru ana odaktır. Bu filmlerde de kendiliğinden bir yaşantı düzeninin meydana getirdiği bir dünya karşımıza çıkmaktadır. Bu küçük yerleşim yerinde insanlar birbirlerini tanımaktadırlar. $\mathrm{Bu}$ tanışıklık güven ve ahlaki anlamda bir aradalık duygusunun ve motivasyonun sınırsız olduğu veya bunu bozacak bir düşmanın olmadığı düşüncesini uyandırmaktadır. Bu bağı bozanın ise dışarıda kalan, uzakta olan, gelebileceği bilinen ama beklenilmeyen bir etki meydana getirecek olandır. Bu etki devlet, bürokrasi, ordu şeklinde kimlik kazanmaktadır. Söz konusu filmleri nostalji temsilinin seyri keyif veren, çocuksu ${ }^{18}$ bir dünya göstermesiyle izleyicisi

15 Çalışmamız 2000 sonrası gibi bir tarihsel çerçevelemede bulunsa da Propaganda filmi 90'lar siyasi hicvi ile bu çalışma kapsamındaki nostalji boyutuna dair önemli göstergeler içermesiyle çalışmaya dahil edilmiştir.

16 Bu filmler dışında nostalji özellikleri gösteren filmlerde eklenebilir. Mesela yeniden çevrim örneklerinden Hababam Sınıfı Askerde (Ferdi Ĕ̆ilmez, 2005), Hababam Sını 3.5 (Ferdi Ĕ̆ilmez, 2005) ve Yeşilçam melodramlarının parodisi olan Ömerçip (Zeki Alasya,2003) nostaljiyi bilinçli kullanan filmlerdir. İki filmde de Yeşilçam rüyası hissettirilmeye çalışılır.

17 Bu konuya paralel olarak Amerikan sinemasının 80'ler popüler filmlerinde nostaljiyle birlikte geleneksel aile düşüncesinin muhafazakar birlikteliğini düşünmeyi öneren Michael Ryan ve Douglas Kellner'in "Politik Kamera" (2010: 247-263) adlı çalışması anılmaya değerdir.

18 Çocuksuluk ifadesinin Asuman Suner tarafından da ele alındığını anmak gerekmektedir (2006). Suner, 
için anlamlı ve değerli kılan yönüne ek olarak bu durumu önemli olduğunu söylenebilir. Nostalji, tarihsel olma iddiasında değildir. Nostalji bir dönemin işaretlerini taklit eden veya onları yeniden üreten bir tavır gösterebilir. Bir dönemin havasını sunacak olan her türlü obje, durum, kişi, modalar veya diğer her türlü şey nostaljinin anlatı dilinin unsurlarıdır. Bir öğenin tarihsel varlığından çok onun kitlelerde uyandırdığı ortak anlamlar veya atmosfer değerlidir. Nostaljiyi tarihten yoksun kılan ve onu gerçekdışı, masalsı görülmesine neden olan da budur. $\mathrm{Bu}$ sebepten nostalji temsili ile tarihi ve dönem temsilleri arasında görünür bir fark söz konusudur. İkincisi belgesellik iddiasına sahip ile ilki atmosfer etkisine sırtını yaslamaktadır.

Bu filmleri de anlamlı kılanın Yeşilçam dilinin veya sinemanın rüya sahnesi üreten kitle tüketimine dönük anlatım tarzını kullanırken gerçekleştirmiş oldukları karşılaşma durumudur. Karşılaşılanlar ise ülkenin tarihinde etkili olan, politik, kültürel ve ekonomik seyrini değiştiren darbelerdir. Propaganda'da devlet, köyün etrafından çekeceği sınır yüzünden köyün düzenini değiş̧irir. Vizontele Tuuba'da köyün delikanlıları arasındaki sol-sağ çatışması 12 Eylül askeri darbesiyle mizahi ve karikatürel dolayısıyla saflığını yitirir. Bu sahnelerde film karanlığa gömülürcesine değişimi göstermek ister. Beynelminel'de 12 Eylül darbesinin etkileri küçük bir kasabadaki insanlar üzerine nasıl etkide bulunduğu anlatılır. Şellale`de yine 27 Mayıs askeri darbesi öncesi olaylara yer verilir. Bütün bu filmlerde dışarıdan gelecek olan dönüştürücü güç yakınlaşmaya, içeri girmeye, kendiliğinden varlık bulan saf dünyayı bozucu şekilde gösterilmektedirler. Bu güç içeri girdiğinde suçu belirler. Aslında o ana kadar suç olarak görülemeyecek eylemler, tavırlar işaretler suça dönüşür.

Bu olaylar nostalji temsiline niye girmek zorunda kalmışlardır? Bunun dönemsel açıklamasının 2000 sonrası Türkiye' sinde değişen siyasi paradigmanın geçmiş ile yüzleşme, hesaplaşma duygusunu harekete geçirmesi olduğu iddia edilebilir. Özellikle 12 Eylül askeri darbesinin mimarı Kenan Evren'in ölümüne yakın daha da görünür olan “darbeciler yargılanmalı" gündemi ${ }^{19}$ hesaplaşma başlığında önemlidir. Söz konusu filmler de kaybedilmiş bir dünyanın temsilini sunarlarken birden dönem filmine dönüşür gibi yaşanmış olayları göstermeleri veya hissettirme çabasına da girişiler. Bu durumda filmleri çeken kuşakların dolaylı veya doğrudan darbe ile ilgili yaşamış olduklarını yansıtmak istedikleri görünmektedir. Bunu gerçekleştirirken Yeşilçam benzeri bir atmosfer üretmeleri sinema dili olarak kitlelerin ilgisini çekebilecekleri tanıdık bir dünya meydana getirmelerine neden olmuştur. Yani izleyici kitle için darbenin etkileri evrensel denilebilecek bir iyi/kötü ilgisiyle gösterilmiştir. Ancak söz konusu filmleri eleştirel tutum, dönemsel anlamda çok yönlü bir tartışma ve ideolojik bir bakış içerdiğini söylemek iddialı olacaktır.

Çağan Irmak bu kuşak arasında ön plana çıkartılabilecek isimlerdendir. Irmak»ın 20042005 tarihleri arasında televizyon filmi olarak çekmiş olduğu Çemberimde Gül Oya adlı serisi ve devamında çekmiş olduğu Babam ve Oğlum filmi nostalji temsili açısından kayda değer dönem filmi örneklerindendir. Bunlara da Dedemin İnsanlarn (2011) filmi de eklenebilir. Yine Issız Adam (2008) filmi bu çalışma kapsamına girmese de Irmak sinemasında nostaljinin yerinin olduğunu söyleyebileceğimiz filmlerindendir.

Babam ve Oğlum, darbeden etkilenmiş bir ailenin dramını anlatmaktadır. Darbe gecesini doğum yapmak zorunda kalan eşini, hastaneye yetiştiremeyen Sadık (Fikret Kuşkan) eşine parkta doğum yaptırtır. Eşi hayatını kaybederken, Sadık ömür boyu oğlu ile yapayalnız

kitabında kaybolmuş bir masumiyet ve çocukluk anıları olarak kelimeyi kullanmaktadır.

19 Bu gündem günümüz basınında çok görünür olmasa da son gelişmeleriyle hala devam ettiği görülmektedir. 
kalacaktır. Sadık, darbe ile içeri alınır ve işkence görür. Film, diğer popüler örneklerine göre darbenin meydana getirdiği sert koşulları izleyicisine göstermektedir. Mikro evren olan aile, darbenin meydana getirdiği koşullardan etkilenmiş olur. Sadık gördüğü işkenceler yüzünden hayatı boyunca hasta bir şekilde yaşamak zorunda kalacaktır ve ömrünü doldurmaktadır. Oğlu Deniz'i alıp babasının evine gider. İzleyici bir başka mikro evrene girer ve her şeyden uzak bir aileyi izlemeye başlar. Kendisini saf ve temiz, kendi dünyalarında yaşayan bir çevrede bulur. Baba ve Sadık arasında ise dönemin siyasi görüşleri yüzünden çıkmış olan tartışma ve bitmeyen bir küslük olduğu görülür. Deniz ile dedesi arasındaki mesafe, filmin bir yerine kadar çözülmeyi bekleyen düğümlerden birisi olarak gösterilir. Ancak kısa sürede dede torununa olan sevgisi gösterir. Sadık ise hastalığı nedeniyle ölür. Dramatik yoğunluğun zirve yaptığı film, babasının anısını yaşatmak, onsuz kaldığ anlatır. Dedesinin kendisini mutlu etmek için verdiği kamera ve onun içindeki babasına ait görüntülerle Deniz, bu anıyı yaşatabileceğini fark eder.

Irmak, nostalji temsili açısından dikkat çekici bir yönetmendir. Bu çalışmada görülen filmlerde ortak özelliklerden bir tanesinin karakterden çok tiplemeler ile hikayelerini anlatmalarıdır. Yeşilçam aile ve komedi filmlerindeki gibi belli bir özelliğin vurgulandığ1 tiplemeler, olayların derinliğine girilmesini sınırlı hale getirmektedirler. Irmak'ın filminde de tiplemeler karşımıza çıksa da karakter olmaya başlayan özellikler ile karşılaşılmaktadır. Hesaplaşma ve çatışmaya dair işaretler, mimler bile buna hizmet etmektedir. Baba figürü, aile reisi ve ilkeli ancak içten içe duygusal bir tip olsa da oğluna dair derin pişmanlıklar yaşayan birisidir. Zirve sahne olarak oğlunun cenazesindeki kendisini suçlayan hali buna örnektir. Yine de filmdeki karakterlerin tipleme ile karakterizasyon arasında gidip geldikleri söylenebilir.

Irmak'ın Çemberimde Gül Oya dizisinin bilinçli olarak burada anıldığı söylenmelidir. Dizi film, 12 Eylül'e çıkan bir öykü ile geçmişin mahalle ve aile birimi içinde varlık bulan imkansız bir aşkı anlatmaktadır. Zengin bir ailenin kızı ile solcu bir gencin aşkı, onları saran mutlu mahalle ve aile içinde gösterilirken Yeşilçam sinemasına özgü atmosfere ihtiyaç duyulur ve izleyici bu sahnelerde nostaljik bir dünyanın içinde kendisini bulur. 90'ların mahalle dizilerine dönem dizisi olarak eklenebilecek dizi, onları bir dönemin siyasi sonuçları ve bunları yaşayan karakterlerin dönüşümlerini göstermesiyle aşmış olduğu söylenebilir. Dramatik etkinin yoğunluğu adına Irmak»ın karakterlerin görünür olan veya şablonlaşmış yönlerini derinleştirdiği görülmektedir. Dizinin zirvesi ve beklenen olayının ise 12 Eylül darbesi olması kayda değerdir. Dizi boyunca nostalji temsilinin keyif veren sahneleri akarken olayın meydana getireceği kırılmalar, beklenen travmanın nasıl etkiler oluşturacağı konusunda merak uyandırmaktadır.

Babam ve Oğlum'un bu dizinin kurgusunu arkasına alarak yine 12 Eylül özelinde bu travmatik olayın nasıl bir etki oluşturduğunu göstermesi adına anlamlıdır. Irmak'da bu çalışmadaki diğer örneklerde olduğu gibi travmatik olayın aile ve mahalle gibi kendiliğinden, otantik yaşantısı olan toplumsallığımızın görünümlerinin darbe yüzünden yitirdiğimiz duygusunu izleyicisine vermektedir. Artık bundan sonra her şey değişmiş, bir şeyleri yitirilmiştir. Bugün ise onları anmak, onları yaşama isteğiyle yaşamak kalmıştır. Bundan bir ütopya çıkabilir mi? Böyle bir soru nostaljinin pozitif yönüyle ilgili görülebilir. Ancak burada 90'larla birlikte gelen siyasi söylemlerdeki değişimler, ideolojilerdeki kırılmalar düşünülmeden buna cevap verilemez. Yitirilenleri olduğu gibi yaşama iddiası karşısında onların meydana getirdiği şimdiyi anlamak belki de önerilebilecek bir tutum olacaktır. Böyle bir ideolojik 
bakışın tarih ve geçmişe takılı kalmayan, onları mitleştirmeyen bir bakış olduğunu ve geçmişin izlerinin şimdide bularak yaşamayı önerdiği söylenmelidir.

70'li yıllar unutulmuş ve özlemle anılan yaşantının örneğidir. İlginçtir ki bu dönem Yeşilçam'ın da dönemidir. Yeşilçam filmlerinin döndürüldüğü televizyon kanallarında 12 Eylül'e kadar yoğun bir şekilde anlatılan dönemdir. Bu dönem kaybedilmiş bir geçmiş ve deneyimin alanıdır. Ailenin değerli olduğu, mahalle ve köy gibi yerleşim yerlerinde dostluğun aile düzeyinde yaşandığı, ahlaki erdemlerin korunduğu ve anlamlı olduğu bir evre kendisini göstermektedir.

Çalışma kapsamında ele alınan filmlerin siyasi iktidarın bürokrasi veya darbeler yoluyla bir şeylerin kaybedildiğini savundukları görülür. Olay dönüştürücü gücüyle sonraki toplumsal formu içinde taşır ve bunu tepeden inme şekilde gerçekleştirir. Çatışkılar suni olarak kabul edilmektedir. Onların meydana getirdiği yarılmalar küslükler ve kopuşlar (sol/să̆, baba/oğul, birey/aile ... gibi) sonraki toplumsal formun dağılmış olduğunu ima etmektedir. Bütünlüklü hal yerini yabancılaşmış bireylere, mutsuz toplumsallığa birakmıştır. $\mathrm{Bu}$ nostalji temsili gibi tüketime ve eğlenceye odaklı bir gösterimin aslında alttan altta öne sürmekten vaz geçmediği iddialardandır. Söz konusu filmlerde bu görülmektedir. Elbette bunu gerçekleştirirken bir şeyleri üstün körü geçtiği, dönemin olaylarını derin bir şekilde göstermekten uzak, basmakalıp bir tutum izlenildiği iddia edilebilir. Basmakalıp olana duyulan ihtiyaç (1) olayın genel olarak nasıl alımlandığı, işaretlendiği ile ilgilidir. Mesela 12 Eylül öncesi evreyi kardeşlerin birbirine düşürülmesi olarak görmek gibi. Bu bakış o kadar günceldir ki sınıf çatışması gibi bir tipik kategori bu dönemi anlamak için en azından popüler jargonda ifade edilmez. (2) Basmakalıp ihtiyacı dolayısıyla bir teamülün içinde olunmasını sağlar. (3) En önemlisi ise basmakalıp başka bir anlatım tarzının imkansızlıklarına işaret eder.

Türk sinemasında darbe dönemlerini konu alan filmlere bakıldığında travmatik olanın gösterimine dair zorlanmaların olduğu söylenebilir. 2006 tarihli Eve Dönüş (Ömer Uğur, 2006) filmi darbe döneminde işkence görmüş Mustafa (Mehmet Ali Alabora) karakterinin yaşadıklarını anlatmaktadır. Eve Dönüş, 12 Eylül filmleri gibi gerçekçi bir tutuma sahip olmaya çalışmaktadır. Bunu ise işkence sahneleri ile gerçekleştirmek ister. 80'li yıllardan bu yana '12 Eylül filmleri' olarak başlıklandırılabilecek olan film serisi, nostalji temsilinin rüya sahnelemesine karşılık gerçekçi sahnelemelere başvurmaktadır. Travmatik olay travmanın küçük ölçekli şekilde gösterimiyle verilmeye çalışılmıştır. Darbe, topluma, darbeciler de bireylere zarar vermiştir. İşkence ise tüm bu olanların yaşanmasındaki düzeneğin temsilidir. Sert ve gerçekçi olma iddiası travmayı göze getirme ve onu yorumlayarak izleyicisine dönemsel olayları sunma amacındadır. Ancak bu gösterim tarzının da izleyiciye dönem ile siyasi boyutta hesaplaşma veya yakınlıklar kurma konusunda etkili olduğunu söylemek de iddialı olacaktır. Dönemin olayları ile hesaplaşılmamış olunması sinema perdesinde sürekli tekrar eden anlatımların sıkışmasına da neden olmaktadır. Mustafa' ya işkence edenler kimlerdir? Onlara neler olmuştur? Hesaplaşmak, tarihsel olarak dönemin kayıt altına alınması, toplumsal olarak olayların failleriyle gerçekleşmesidir ${ }^{20} \mathrm{ki}$ bunun olamaması olayların temsilinde de bir şeyleri askıya alma mecburiyetine neden olabilmektedir.

Zaman değiştikçe kuşaklar bu olayları konu edebilecek kelimelerden, işaretlerden, görüntülerden uzaklaşmakta veya başka ifade imkanları meydana getirebilmektedir. Nostalji

20 2000'li yıllarda Kenan Evren' in yargilanma isteği bir tür hesaplaşma isteğini göstermektedir. (https://bianet. org/biamag/siyaset/139436-evren-sahinkaya-davasi-nda-12-eylul-yargilaniyor-mu) 
veya gerçekçi gösterimin travmatik olan ile hesaplaşma veya onu geride kalmış bir geçmiş ve deneyimler dünyasının bozguncusu olarak gösterme amacı kesintili olsa da anlamını korumaya devam edecektir.

\section{Nostalji Temsilinin Türk Sinemasındaki Şimdisi}

Cem Yılmaz'ın G.O.R.A. (Ömer Faruk Sorak, 2004) ile başlayan ve A.R.O.G. (Cem Yılmaz, Ali Taner Baltacı, 2008) ile devam eden serinin son filmi Arif V. 216 (Kıvanç Baruönü, 2018) nostalji konusunda güncel anlamda bir şeyler söylemektedir. Yılmaz' in serisinin üzerine oturduğu ana eksen parodidir. Türler parodisi, bilinen popüler filmlerin sahnelerinin parodisi, karakter parodisi son filmde nostalji temsilinin parodisini yapar. Arif V. 216 70'lere yapılan zaman yolcuğuyla dönemin Yeşilçam sinemasına ait tüm işaretleri izleyicine sunar. Sadri Alışık, Ayhan Işık gibi ünlü oyuncular, 70'lerin mahalle hayatı ve tipik karakterleri, dönemin atmosferini taşıyan şarkılar ve ortam izleyiciye nostalji geçidi sunarlar. Arif (Cem Yılmaz) karakteri bu dönemin saflığıyla dalga geçse de $\mathrm{O}^{\prime}$ da kendisini bu döneme kaptırmaktan geri alamaz. Diğer filmlerde olduğu gibi 70’ler saf, temiz, aile ve mahallenin yüceltildiği, erdemin asıl olduğu kayıp zamandır. Film, bu zamanın parodisi olsa da, Yeşilçam estetiğini kullanarak üzerinde yükseleceği bir arka plan meydana getirse de kayıp olan deneyime değer vermeyi ihmal etmemektedir. Arif V. 216'y ayrıca anlamlı kılanın ise 90'l yılların sunumuna verdiği yerdir. Filmin nostalji anlamında ikinci dönemi ise 90'lı yıllardır. Filmde bu evreye ait şarkılara bolca yer verilmiştir ve 70'li yıllar ile buluşturulur. Anakronik özellik gösteren bu ilişki, filmin görsel ve işitsel zenginliğini artırmak için anlamlı görünmektedir. Ancak bir başka nostalji evresinin 90'lı yılların göze getirildiği de gözardı edilemez. Arif V. 216 bu çalışmadaki filmlerden farklı olmasını da bu dönemi işaretlemesiyle göstermektedir. İlk başta film, nostalji temsilini kullanırken travmatik boyutu hissettirme derdinde değildir. Zamanda yolculuk temasını işlese bile, benzer yabancı film örneklerinden farklı olarak, tarihsel kimi olayların parodik düzeyde olsa bile dokundurtmasını yapmaz. Filmdeki zamansal kırılmaların ana nedeninin 216 (Ozan Güven) karakterinin değişimi, saf ve temiz biriyken diktatöre dönüşmesidir.

Arif V. 216 nostalji temsilinin tüketim karakterine iyi bir örnektir. Müzikler, giyim kuşam, dönemin karakterleri, kimi sözel ifade formları ve diğer dönem işaretleri tüketilmek için akmaktadırlar. Film, günümüz Türkiye ana akım sinemasının nostalji tutumundaki tavrında değişmeyen yönleri tekrar etmektedir. Yeşilçam estetiğini arkasına alarak, 70'li yılların saf ve temiz zamanlar olduğunu, bu dönemin yaşantısının anlamını bu filmde tekrar etmektedir. Arif, ilk sahnelerde gelmiş olduğu 70'li yıllar ile dalga geçse de devam eden sahnelerde değişim yaşayarak bu döneme saygı duymaktan kendisini alamaz.

90'lı yılların sahneye çıkması, Yeni Türk sinemasının gerilerde bıraktığı bir evreyi nostalji sahnesine taşıyabileceğini söylemektedir. Arif V. 216 bunun ilk örneği olarak görülebilir. Film bu evreyi özellikle şarkılar üzerinden göstermeyi tercih etmiştir. Bunun nedenini ise 90'lı yılların nostaljisinin üretirken dönemi travmatik olan olay veya olayları ile karşılaşmayı şimdilik göze almamış olmasıdır. Nostalji temsilini anlamlı kılan özelliklerden birisinin bu olduğu iddia edilebilir. Nostalji, kaybedilmiş deneyime ve zamana bir ağıt olsa da buna neden olan olayların anılmasıyla o dönemi anlamanın imkanı olmaktadır.

\section{Sonuç}

Bu çalışmada amaçlanan 2000 sonrası Türkiye'sindeki ana akım kimi filmlerde nostalji 
temsili ve geçmişin nasıl icat edildiğini bu örnekler ile açıklamaktır. Nostalji ve nostalji temsili, bu çalışma özelinde travmatik olay olarak darbe veya benzeri iktidar ile ilgili müdahalelerin nasıl eşik altından gösterildiği, bunların organik toplum, topluluk düşüncesini bozucu unsur olarak gösterildiği etrafında ilerlemiş olan buraya kadar ki kısımda nostaljinin kurucu, tazeleyici yönüne çok da değinilmedi. Nostaljinin bu yönüyle modern olma nedenini bir kelimede saklı görebiliriz. Bu kelime ütopyadır.

Nostalji, kaybın gerçekleşmeden önceki organik dünyayı, temiz ve saf olanı sunma iddiasındadır. Hatırlamak ve inşa etmek, belleği tazelemek ve deneyimi oluşturmak, böylesi bir durumun içinde düşünülmesi yadırgatıcı gibi görünse de nostaljik her türlü temsil bunlara dairdir. Geçip gitmiş zamanın ve deneyimin, geçmişin hissedilmesi veya hissettirilmesi onun özelliğidir. Nostaljiye duyulan ihtiyacın romantik melankoliden kitle kültürünün modalarına kadar birçok nedeni söz konusudur. Bunlardan bir tanesinin de temsil zorluklarını aşmak olduğu eklenmelidir. Bu çalışmada ele alınan filmlerde bunu görmek de mümkündür. Bu filmler endüstri açısından çok izlenir ve tüketilir görülebileceği gibi bir ihtiyacı kendinde barındırmaktadırlar. Bu ihtiyaç, toplumsal hafızada yeri olan ancak eşik altı edilmiş gibi duran darbe ve ona benzer toplumsal kırılmalar meydana getiren olaylar ile yüzleşmek, onların şimdideki etkilerini göstermek veya hissettirmektedir.

Nostalji temsili böylesi bir semptomatik boyuta kendiliğinden sahiptir. Nostalji nesneleri, imgeleri, işaretleri bir uzaklaşma, içten olmayan bir hatırlama gibi duran edimi öneriyor olsa da hepsi de bir belirti olarak farklı anlamları içinde barındırmaktadır. Bir yönüyle keyif verici bir dünya sunumu, diğer yönde idealize edilmesi, bir başka yönde ise böylesi bir sahte hatırlamanın içerdiği yıkıcı etkilerin mevcudiyet kazanması. Nostalji temsili, tıpkı her türlü temsil tarzında olduğu gibi, bunu göstermektedir. Yukarıda anılan filmler de iktidarın görünür hale getirildiği filmlerdir.

Ütopyanın anlamı bir imkan sunmasıyla kendisini göstermektedir. Nostalji ister inandırıcı ister inandırıcı olmayan şekilde geçmişi sunsun, geleceğe doğru atılmış bir ideali, bir çekirdeği ütopya ile içinde barındırmış olur. Bu olması gereken yaşantının özlemini hissetmekle eş değer görülebilir. Ütopyacı düşünme de onun bu potansiyelini gelecek tahayyülü içinde bir değer ve tasarım olarak görmektir. Modernist kültüre özgü ütopyaların, günümüz siyasi perspektifinde gücü ve etkisinin olmadığını söylemek ise abartılı olmayacaktır. İşte burada nostaljinin üretici gücünün yitimini ütopyanın bu statüsü ile ilgili olarak görmek mümkündür.

Çalışmamız kapsamında 2000 sonrası Türkiye sinemasından alınan örneklerin başka bir sunumu öne sürdüğünü, bunun ütopya değil de eleştirel bir yaklaşım sunduğu iddia edilebilir. Bu eleştirellik darbe ve benzeri iktidar merkezli olayların toplumu parçaladığı, onu dönüştürdüğü ve bunu gerçekleştirirken şimdiye bir projeksiyon sunuyor olduğudur. Çalışmamızın son kısmında günümüz Türkiye sinemasında nostalji seyrine örnek olarak verilen Arif $V .216$ filminin bu eleştirel tutumu tamamen paranteze aldığını ve kendisinden önceki temsil tarzını izleyerek bir nostalji temsili ürettiği gösterilmeye çalışılmıştır. Burada ise güncel kültürel yaşantı, siyasi bilinç, politik tavırlar devreye girmektedir.

Çalışma kapsamında alınan örneklerin çoğu 12 Eylül özelinde "hesaplaşma" gündemi içinde varlık bulmuştur. Dönemin reel politikasına kadar uzanan bu hesaplaşma gündemi, sinemadaki darbe ve onun dönüştürücü rolünü perdeye getirilmesi konusunda fikir vermektedir. Nihayetinde nostalji nesnelerinin popülerliği alımlayıcısı kitlelerin gündemleriyle ilgilidir. Bu gündem etki gücünü yitirmeye başladığında ise bu temanın ana 
akım popüler sinemada görünürlüğünü yitirmeye başladığı söylenebilir ${ }^{21}$. Burada darbe ve benzeri olayları konu edilen 2000 sonrasında çekilmiş ve vizyona girmiş, çalışma kapsamında isimleri geçen filmlerin ise eleştirel bir perspektif sunma iddiasında olmaktan çok olayları anlatma konusunda anlamlı olabilecek bir çeşitlilik göstermeye çalıştıkları iddia edilebilir. İlk olarak bu filmlerin Yeşilçam sinemasına ait bir gösterimi kullandığı, yapısal ve atmosfer olarak onu izledikleri görülmektedir. Ancak bu filmlerde tipik gösterim tarzlarında sıkışmış olmaları nedeniyle eleştirel bir güç meydana getirmemiş, bunu da amaçlamamışlardır. Çağan Irmak yönetmenliğindeki filmlerin diğerleri arasındaki fark çalışmamız içinde vurgulanmıştır. Bunun nedeni Irmak'ın sinemasında nostalji temsilinin tiplerle sınırlı kalmayıp, izleyici için empati oluşturabilecek bir karakterizasyon özelliği göstermesi denilebilir. Bu ise karakter ile iktidar arasındaki çatışmada izleyiciyi taraf olma durumuna götürebilmiştir.

Nostalji temsilinin pratikliği gerçekliğe tarafgir olmaktan veya gerçekliği gösterme zorluklarından kaçabilmesinde yatmaktadır. Nostalji, fantezi boyutunda dolaşmak demektir. Perdedeki dünya ise hayal edilen dünyadır. Bu Marksist perspektifin ürün olan kültür endüstrisinin kitlelere atalet duygusunu aşılması veya sürdürmesi anlamına gelebilmektedir ${ }^{22}$. Diğer taraftan bunu gerçekliğe karşı alternatifsizlik kalmak gibi oldukça zor ve kaldırılması güç durumu bertaraf etmenin yolu olarak görmek gerekmektedir. 2000 sonrası Türkiye sinemasında da nostaljinin görevinin bu olduğu iddia edilebilir.

\section{Kaynakça}

Armes, Roy, (2011). Sinema ve Gerçeklik. İstanbul: Doruk Yayınları.

Arnheim, Rudolf, (2002). Sanat Olarak Sinema. İstanbul: Öteki Yayınları.

Baker, Ulus, (2010). Kanaatlerden İmajlara. İstanbul: Birikim Yayınları.

Başekim, Sezen Gürüf, (2015). Türk Sinemasında Nostalji: 2000-2011. Ankara: Gazi Sosyal Bilimler Enstitüsü.

Baudrillard, Jean, (2018). Tüketim Toplumu. İstanbul: Ayrıntı Yayınları.

Berlin, Isaıh, (2004). Romantikliğin Kökleri. İstanbul: Yapı Kredi Yayınları.

Berman, Marshal, (2003). Katı Olan Her Şey Buharlaşıyor. İstanbul: İletişim Yayınları.

Bornstein, Thorsten-Botz, (2011). Filmler ve Rüyalar. İstanbul: Metis Yayınları.

Boyn, Svetlana, (2009). Nostaljinin Geleceği. İstanbul: Metis Yayınları.

Calinescu, Matei, (2010). Modernliğin Beş Yüzü. İstanbul: Küre Yayınları.

Cassin, Barbara, (2018). Nostalji. İstanbul: Kolektif Kitap.

21 Son dönem ana akım sinemada kahraman odaklı filmlerin popüler olduğu görülmektedir. Ayla (2017) ve Müslüm (2018) gibi filmler seyirci kitlesi olarak gözle görülür bir ilgi görmüştür. Konuları açısından iki filmde kişi odaklı ve gerçek bir hikayeye dayalıdırlar.

22 Marx'ın ise bu konuda dönemi sanatına karşı eleştirel bir bakış sergilediği, geçmişin sanat formlarının güncel gerçeklik ile bağları kopuk olduğunu düşündüğü, bu düşüncenin Marksist estetik ve sanat teorisi bağlamında farklı görünümler gösterdiği görülür. Bu konuda bir kaynak için Margaret A. Rose'un "Marx'ın Kayıp Estetiği” (2015) kitabı verilebilir. Rose, kitabında Marx'ın sistematik olmayan sanat ve estetik düşüncelerini biyografik ve düşünsel anlamda Marx'ın dönemine bakışı etrafında özel örneklerle işlemekte, kendi zamanındaki kimi sanat formlarının nasıl atalet duygusunu ürettiğini ve sürdürdügünü anlatmaktadır. 
Claudon, Farncis, (2006). Romantizm Sanat Ansiklopedisi. İstanbul: Remzi Kitabevi.

Crary, Jonathan, (2004). Gözlemcinin Teknikleri. İstanbul: Metis Yayınları.

Cross, Gary, (2018). Tüketilen Nostalji. İstanbul: The Kitap.

Çetin, Adnan, (2010). Bir Kavramın Kısa Tarihi: 'Mahalle Baskısı'. Mukaddime Sayı 3 içinde, ss. 81-92. Mardin Artuklu Üniversitesi Sosyal Bilimler Enstitüsü Dergisi.

Deleuze, Gilles, (2004). Proust ve Göstergeler. İstanbul: Kabalc1 Yayınları.

Esen, Halim ve Vakur Kayador, (2009). Yavuz Turgul Sinemasında Nostalji. Selçuk Üniversitesi İletişim Fakültesi Akademik Dergisi içinde cilt: 6 sayı: 1 ss. 144-153 , Konya: Selçuk Üniversitesi İletişim Fakültesi.

Freud, Sigmund, (2002). Metapsikoloji. İstanbul: Payel Yayınları.

Frisby, David, (2012). Modernlik Fragmanları. İstanbul: Metis Yayınları.

Jay, Martin, (2012). Deneyim Şarkıları. İstanbul: Metis Yayınları.

Kolker, Robert Phıllıp, (2010). Değişen Bakış. İstanbul: De ki Yayınları.

Pezzella, Mario, (2006). Sinemada Estetik. İstanbul: Dost Kitabevi.

Rose, Margaret A. (2015). Marx’ın Kayıp Estetiği. İstanbul: Ayrıntı Yayınları.

Ryan, Michael ve Douglas Kellner,(2010). Politik Kamera. İstanbul: Ayrıntı Yayınları.

Sass, Louis A., (2013). Delilik ve Modernizm. İstanbul: Alfa Yayınları.

Sayın, Zeynep, (2003). İmgenin Pornografisi. İstanbul: Metis Yayınları.

Simmel, Georg, (2003). Modern Kültürde Çatışma. İstanbul: İletişim Yayınları.

Suner, Asuman, (2006). Hayalet Ev. İstanbul: Metis Yayınları.

Taylor, Charles, (2014). Seküler Çă̆g. İstanbul: Türkiye İş Bankası Yayınları.

Touraine, Alain, (2000). Modernliğin Eleştirisi. İstanbul: YKY.

Yılmaz, Ali, (2015). Karanlık Vardiya 90'lı Yılların Politik Arşivi. İstanbul: Doğan Kitap.

Wagner, Peter, (2005). Modernliğin Sosyolojisi. İstanbul: Ayrıntı Yayınları.

Zizek, Slavoj, (2003). Kırılgan Mutlak. İstanbul: Metis Yayınları.

Zizek, Slavoj, (2004). Yamuk Bakmak. İstanbul: Metis Yayınları.

https:/ / bianet.org/biamag/ siyaset/139436-evren-sahinkaya-davasi-nda-12-eylulyargilaniyor-mu (Erişim tarihi: 03.03.2018). 